\title{
CHEMICAL AND PHYSICAL COMPARATIVE STUDY OF THE EFFECT OF WET AND DRY BENEFICIATION OF KANKARA KAOLIN
}

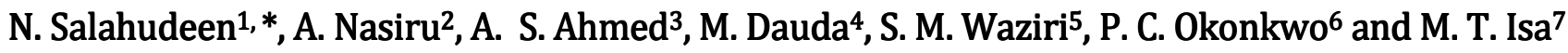

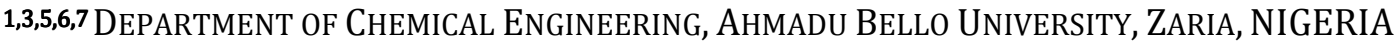 \\ 2DEPARTMENT OF CHEMiCAl ENGINEERING TECHNOLOGY, FEDERAL POLYTECHNIC, NASARAWA, NIGERIA \\ 4DEPARTMENT OF MECHANICAL ENGINEERING, AHMADU BELLO UNIVERSITY, ZARIA, NIGERIA \\ Email Addresses: 1 nusdeen@yahoo.co.uk, 2abumuhseenchet@gmail.com,3asahmed2007@yahoo.com, \\ 4muhammaddauda@yahoo.com,5smwaziri@gmail.com,6chemstprom@yahoo.com,7mtisaz@yahoo.com
}

\begin{abstract}
Chemical and physical comparative effect of wet and dry beneficiation processes for purification of kaolin was studied. X-ray flourescence XRF and particle size analysis of kaolin clay before and after beneficiation were carried out. The Si/Al ratio of the raw kaolin which was 1.90 decreased by 1.6 and $17.9 \%$ after the wet and dry beneficiation processes respectively. The clay content of the raw clay which was 48 wt\% was improved to 73 wt\% after the dry beneficiation while the impurity content was reduced from 52 to 27 wt\%.
\end{abstract}

Keywords: Kaolin, dry, wet, beneficiation , XRF, particle size

\section{INTRODUCTION}

Kaolin is a group of clay minerals regarded as the 1:1 structural class. It consists of non-phyllosilicate minerals such as carbonates, feldspars and quartz together with the (hydr)oxides of iron and aluminum which are referred to as non-clay constituent or accessory minerals. [1, 2]. Kaolin chemical formula is represented as $\mathrm{Al}_{2} \mathrm{Si}_{2} \mathrm{O}_{5}(\mathrm{OH})_{4}$. Its structure is made of tetrahedral silica $\left(\mathrm{SiO}_{2}\right)$ and octahedral alumina $\left(\mathrm{Al}_{2} \mathrm{O}_{3}\right)$ in 1:1 $(\mathrm{T}-0)$ layers in an alternative stagging arrangements. Kaolin is one of the most abundant minerals in soils and sediments, it is a common weathering product of many tropical and sub-tropical soils $[1,3]$. As a clay material, kaolin is known for diverse applications such as usage in production of refractories and wide spectrum of ceramics $[4,5]$ in several industries. As natural material, kaolin is normally extracted with some inherent impurities which makes the clay unsuitable for use in the industrial applications where kaolin are needed $[6,7]$. The clay is therefore purified to make it suitable for industrial applications. Various purification processes are normally used for kaolin purification, the common ones include dry purification (using cyclone), wet purification (using chemical and chemical free method), hydro-cyclone and magnetic method. The most popular of these methods are the dry and the wet beneficiation methods. The progress in the purity of clay at the end of these purification processed can always be monitored by the change in their physicochemical properties, which can be determined by chemical composition analysis such as X-ray fluorescence (XRF) and physical analysis such as particle size analysis. Most of the kaolin wet beneficiation plants across the world employ the chemical free wet method [8]. This work compares the purification effects of the chemical free wet beneficiation process and the dry beneficiation process.

\section{MATERIALS AND METHODS}

\subsection{Materials}

Raw kaolin clay was mined from Kankara Local Government Area of Katsina State, Nigeria. Laboratory tap borne water, plastic drum, buckets, mortar and pestle, air cyclone, glass cylinders, thermometer, Fahrenheit hydrometer, Bouyoucos, electric mixer with dispersing cup, balance sensitive to $0.01 \mathrm{~g}$, sodium hexametaphosphate, deionized water and XRF machine. 


\subsection{Methods}

The raw clay was wet beneficiated as presented in Ahmed et al., [9] and Salahudeen et al., [10]. Dry beneficiation was carried as presented in Audu et al., [11].

XRF analysis was carried out using Minipal 4, Pananalytical X-ray fluorescence analyzer. The sample was pre-treated by grinding. The clay sample was pulverized and homogenized using agate mortar and pestle. The pulverized sample was pressed into pellet using starch as a binder in a proportion $1: 10$ by weight clay-to-binder. About $200 \mathrm{mg}$ of the pellet was prepared to about $25 \mathrm{~mm}$ diameter and placed in the sample holder of the XRF machine. The machine was put on and the analysis was carried out.

Particle size analysis was carried out using the hydrometer method, the method was based on Stoke's law governing the rate of sedimentation of particles suspended in water. 5\% dispersing solution was prepared by dissolving $50 \mathrm{~g}$ of sodium hexametaphosphate, $\mathrm{Na}_{6}\left(\mathrm{PO}_{3}\right)_{6}$ in deionized water. $100 \mathrm{ml}$ of the dispersing solution was diluted to 980 $\mathrm{ml}$ using deionized water in a $1000 \mathrm{ml}$ cylinder. This mixture was the blank. $50 \mathrm{~g}$ of the clay was weighed and transferred to the dispersing cup and the weight was recorded. $100 \mathrm{ml}$ of the $5 \%$ dispersing solution was added. The dispersing cup was attached to mixer and the sample was mixed for $60 \mathrm{sec}$. The suspension was transferred from the dispersing cup to a $1000 \mathrm{ml}$ cylinder. The cylinder was filled to the $1000 \mathrm{ml}$ mark with deionized water and allowed to stand overnight to equilibrate. At the beginning of each set, the temperature, and the hydrometer reading of the blank, were recorded. To determine the density the plunger was inserted into the suspension, was mixed for about $30 \mathrm{sec}$. until a uniform suspension was obtained. The plunger was removed and the hydrometer was gently inserted into the suspension after $40 \mathrm{sec}$ and the hydrometer reading was recorded, this was the amount of silt plus clay suspended. The hydrometer was reading was also recorded again after 6 hours, $52 \mathrm{~min}$, this was the amount of clay in suspension. The silt has settled to the bottom of the cylinder by this time. Time and density corrections were determined in run and the \%clay, \%silts and $\%$ sand were evaluated using Equations $1-3$.

\subsection{Temperature and density corrections}

Density of the blank was subtracted at each reading from the corresponding density reading of the sample. 0.2 un it to the readings of the samples for every $1^{\circ} \mathrm{F}$ above 67

${ }^{\circ} \mathrm{F}$, and subtract 0.2 unit for every $1^{\circ} \mathrm{F}$ below $67^{\circ} \mathrm{F}$.

$$
\begin{gathered}
\% \text { Clay }=\frac{\text { corr. hyd. reading at } 6 \mathrm{hrs}, 52 \mathrm{~min} \cdot \mathrm{x} 100}{\text { weight of clay }} \\
\% \text { Silt }=\frac{\text { corr. hyd. reading at } 40 \mathrm{sec} \cdot \mathrm{x} 100}{\text { weight of clay }} \% \text { Clay } \\
\% \text { Sand }=100 \%-\% \text { Silt }-\% \text { Clay }
\end{gathered}
$$

\section{RESULTS AND DISCUSSION}

\subsection{Chemical Composition}

Table 1 presents the chemical composition of the raw, wet beneficiated and dry beneficiated kaolin. It could be observed that the Si/Al ratio of the raw clay which was 1.90 , decreased by 1.6 and $17.9 \%$ after the wet and dry beneficiations respectively. The decrease in the $\mathrm{Si} / \mathrm{Al}$ ratio could be attributed to the washing away of silica during the wet beneficiation and its successful separation based on density differences during the dry beneficiation process.

Table 1. XRF results of the Kankara kaolin and metakaolin

\begin{tabular}{cccc}
\hline Metallic & \multicolumn{3}{c}{ Sample/Composition (wt\%) } \\
\cline { 2 - 4 } & Raw & Wet & Dry \\
\hline $\mathrm{Al}_{2} \mathrm{O}_{3}$ & 28.43 & 27.81 & 35.2 \\
$\mathrm{SiO}_{2}$ & 54.21 & 52.04 & 55.0 \\
$\mathrm{Na}_{2} \mathrm{O}$ & 0.22 & 0.57 & 0.36 \\
$\mathrm{~K} 2 \mathrm{O}$ & 3.90 & 1.82 & 1.18 \\
$\mathrm{MgO}$ & 0.41 & 0.44 & 0.21 \\
$\mathrm{CaO}$ & 1.86 & 1.19 & 0.66 \\
$\mathrm{CuO}$ & 0.02 & 0.02 & $\mathrm{ND}$ \\
$\mathrm{TiO}_{2}$ & 0.11 & 0.12 & 0.08 \\
$\mathrm{Fe}_{2} \mathrm{O}_{3}$ & 0.80 & 0.93 & 0.82 \\
$\mathrm{LOI}$ & 9.74 & 14.70 & 6.40 \\
$\mathrm{Si} / \mathrm{Al}$ & 1.90 & 1.87 & 1.56
\end{tabular}

*ND: Not determined.

It could be observed that there were some appreciable reductions in the $\mathrm{K}_{2} \mathrm{O}$ and $\mathrm{CaO}$ before and after beneficiation. The reductions were more pronounced in the dry beneficiation product; $\mathrm{K}_{2} \mathrm{O}$ reduced by $53 \%$ and $\mathrm{CaO}$ reduced by $36 \%$ for the wet beneficiation whereas $\mathrm{K}_{2} \mathrm{O}$ reduced by $70 \%$ and $\mathrm{CaO}$ reduced by 
$65 \%$ for the dry beneficiation. The reductions likely occurred as a result of washing off of soluble salts of potassium and calcium during the wet beneficiation process and effective separation based on density difference of the potassium and calcium compounds during the dry beneficiation. $\mathrm{MgO}$ and $\mathrm{TiO}_{2}$ were rather increased slightly after the wet beneficiation whereas they reduced by 49 and $27 \%$ respectively after the dry beneficiation. CuO remained unchanged after the wet beneficiation whereas it was completely eliminated after the dry beneficiation. This was likely because the $\mathrm{CuO}$ impurity was from the silt or/and the quartz component of the raw kaolin which were more effectively removed during the dry beneficiation than during the wet beneficiation. It is worth noting that $\mathrm{Na}_{2} \mathrm{O}$ and $\mathrm{Fe}_{2} \mathrm{O}_{3}$ had rather increased after both beneficiation processes, it was not clear what was responsible for the increment, however, the same trend have been reported for Kankara clay by other researchers [12]. The loss on ignition (LOI) of the raw kaolin was $9.74 \mathrm{wt} \%$, it increased by $51 \%$ and reduced by $32 \%$ after the wet and dry beneficiations respectively.

\subsection{Particle size analysis}

Table 2 presents the particle size distribution results of Kankara kaolin using the hydrometer analysis. \%clay, \%silts and \%sand were determined using Equations $1-3$, the sum of \%silts and \%sand was taken as the \%impurities of the kaolin. It could be observed that the raw kaolin contained $48 \mathrm{wt} \%$ clay and $52 \mathrm{wt} \%$ impurities. These impurities were likely quartzs and other impurities such as silts.

Table 2. Particle size distribution analysis of Kankara

\begin{tabular}{ccc}
\multicolumn{3}{c}{ kaolin } \\
\hline Sample & Clay (wt\%) & Impurities (wt\%) \\
\hline Kaolin feed & 48 & 52 \\
Overflow & 73 & 27 \\
Underflow & 48 & 52 \\
\hline
\end{tabular}

After the dry beneficiation of the kaolin using cyclone the purity of the overflow product was improved; raising the clay content to $73 \mathrm{wt} \%$ and reducing the impurity content to $27 \mathrm{wt} \%$. The observed reduction in the imprurity content was likely due to the fact that during the particle size analysis the agglomerated clay particles were interpreted as impurities due to the higher density of the agglomerate. However the dry beneficiation resulted into splitting the agglomerates.
The underflow contained 48 wt $\%$ clay (lower than the $73 \mathrm{wt} \%$ observed in the overflow) because it was expected to contain the denser impurities removed from the overflow product. Although, it would be observed that the clay content of the underflow was the same as it was in the kaolin feed, whereas it would ordinarily be expected that the clay content of the underflow product be lower than it was in the feed; simply because the denser impurities removed from the overflow were expected to be collected at the underflow. Nevertheless, the reason for the disparity in the observed and expected figures was likely because not all the broken agglomerated clay in the feed existed as individual particles, some still existed as smaller agglomerates having slightly higher densities than individual clay particles, therefore such smaller agglomerates were collected at the underflow due to their higher densities.

\section{CONCLUSION}

The dry beneficiation was more effective than the wet beneficiation in improving the purity of the clay. The dry and wet beneficiations reduced $\mathrm{K}_{2} \mathrm{O}$ by 70 and $53 \%$ respectively; $\mathrm{CaO}$ by 65 and $36 \%$ respectively. $\mathrm{CuO}$ remained unchanged after the wet beneficiation whereas it was completely eliminated by the dry beneficiation.

\section{ACKNOWLEDGMENT}

The authors gratefully acknowledge Petroleum Technology Development Fund (PTDF) Abuja and Department of Chemical Engineering, Ahmadu Bello University, Zaria.

\section{REFERENCES}

[1] Hughes, J. C., Gilkes, R. J. and Hart, R. D. "Intercalation of Reference and Soil Kaolins in Relation to Physico-Chemical and Structural Properties", Applied Clay Science, Vol. 45, 2009, pp24-35.

[2] Bergaya, F. and Lagaly, G. Handbook of clay science, Elsevier, Amsterdam, Netherlands, 2nd edition, 2013.

[3] Miranda-Trevino, J. C. and Coles, C. A. "Kaolinite Properties, Structure and Influence of Metal Retention on pH, Applied Clay Science, Vol. 23, 2003, pp 133-139.

[4] Moorkah, H. I. and Abolarin, M. S. Investigation of the Properties of Locally Available Dolomite for Refractory Applications", Nigerian Journal of Technology, Vol. 24, N. 1, 2005, pp 79-86. 
[5] Anih, L. U. "Indigenous Manufacture and Characterization of Electrical Porcelain Insulator", Nigerian Journal of Technology, Vol. 24, Number 1, 2005, pp 1-7.

[6] Asmatulu, R. "Removal of the Discoloring Contaminants of East Georgia Kaolin Clay and its Dewatering", Turkish J. Eng. Env.,Sci, Vol. 26, 2002, pp 447-453.

[7] Chandrasekhar, S. and Ramaswamy, S. Influence of mineral impurities on the properties of kaolin and its thermally treatred products.Applied Clay Science, Vol. 21, 2002, pp133-142.

[8] Murray, H. H. (2006). Applied Clay Mineralogy: Ocurrences, Processing and Application of Kaolins, Bentonites, Palygorskite-Sepiolite, and Common Clays. "Development in Clay Science", 2 ${ }^{\text {nd }}$ Edition, Elsevier, Amsterdam.

[9] Ahmed, A. S., Salahudeen, N., Ajinomoh, C. S., Hamza, H. and Ohikere, A. "Studies on Mineral and
Chemical Characteristics of PindigaBentonitic Clay", Petroleum Technology Development Journal, Vol. 2 Number. 1, 2012, pp 55-62.

[10] Salahudeen, N., Ahmed, A. S., Ajinomoh, C. S., and Hamza, H. "Surface Area Enhancement of Pindiga Bentonitic Clay for Usage as Catalyst Support", Petroleum Technology Development Journal, Vol. 2 Number 2, 2012, pp 65-73.

[11] Audu, N., Ahmed, A. S., Okonko, P. C. and Isa, M. T. "Design and Fabrication of Air Cyclone for Kaolin Clay Purification", Book of extended abstracts of the 42nd Annual General Meeting, Conference and Exhibition of the Nigerian Society of Chemical Engineers, Held at Nicon Luxury, Abuja. 2012.

[12] Edomwonyi-Otu, L. C., Aderemi, B. O., Ahmed, A. S., Coville, N. J. and Maaza, M. "Influence of Thermal Treatment on Kankara Kaolinite", Opticon 1826, Vol. 15 Number 5, 2013, pp 1-5. 